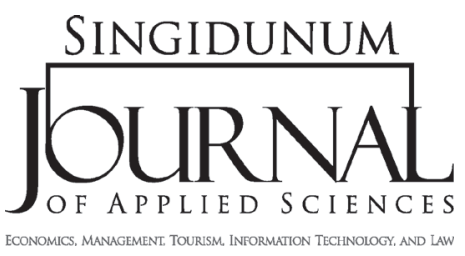

SINGIDUNUM JOURNAL 2013, 10 (1): 28-38

ISSN 2217-8090

UDK: 004.7:338.48; 007:004

DOI: $10.5937 /$ sjas1301028R

Review paper/Pregledni naučni rad

\title{
THE ROLE AND POTENTIAL OF GLOBAL DISTRIBUTION SYSTEM AMADEUS FOR TOURISM DEVELOPMENT AT THE GLOBAL LEVEL
}

\section{Ljiljana Radulović*}

A PhD student at Mediterranean University, MTS - Montenegro Tourism School

Maršala Tita Street, Bar, Montenegro

\begin{abstract}
:
Globalization, development and implementation of new technologies, new consumer trends, concern for the natural environment and other factors, have emphasized the diversity and complexity of the tourism industry. For these reasons, the tourism industry in recent years has focused its activities towards the information and technological infrastructure and global electronic connection in order to overcome border barriers and establish relationships with providers and tourists as well as with travel agencies and tour-operators.

The development of information technology and evolution of airline reservation systems of individual airlines have led to the development of the Global Distribution Systems (GDS), recognized as a worldwide computerized reservation network that electronically connects the tourist offer with the tourist demand.

As a result of the recognized challenge tourism has been facing in recent years, the main goal of this review would be to emphasize the role and importance of the leading GDS Amadeus in order to highlight its potential for the tourism development at the global level. The research and methodology of this review are based on the analysis of data collected from primary and secondary sources, through which we shall, by using deductive approach to theoretical assumptions and analytical approach to quantitative indicators, reach significant individual findings. At the end of the review through summary conclusions, we shall attempt to give a scientific justification of the research, and draw attention to the importance of continuous monitoring and adjustment to changes in the tourism market, in order to highlight the main potential of information technology applications for tourism development.
\end{abstract}

\section{Key words:}

globalization,

tourism,

information technology,

GDS Amadeus.

\section{INTRODUCTION}

Tourism can be characterized as a complex system whose development is conditioned by constant changes in the tourism market, which is especially prominent due to recent changes in the technological environment that have emphasized the application of global distribution systems, which provide a quick and adequate exchange of full, meaningful and timely information to the tourism sector.
The aim of this paper is to emphasize the role of the GDS Amadeus, as a new technology, whose distribution and IT solutions enable interconnection of all elements of tourism, thus providing an efficient business system users and unique tourist services to end users - tourists.

The first part of the review points out the global nature of tourism and predictions concerning the future tourism development at world level, as an introduction to highlight the global distribution systems 
as a product of modern information technologies that can be seen as an important development factor of international tourism.

The second part of the review will cover the basic tasks and GDS Amadeus products, which is recognized as the leader of the established and extensive network of users. It points out the basic structure and operating results of GDS Amadeus in order to highlight the importance of this system for the development of world tourism industry.

Finally, we hope that the application of theoretical and practical approaches to research has resulted in conclusions that will emphasize the importance of implementing the product of modern information technology as an adequate response to the dynamic and complex nature of the tourism industry that requires new forms of organization and business approach that will provide the long-term development of tourism on a global scale.

\section{GLOBAL NATURE OF TOURISM}

The expansion of tourism is reflected in the realized tourist turnover that defines tourism as a dynamic category and in constant evolution. Modification of the old and creation of new demands of tourists for another "unseen" indicates the global nature of tourism destinations. The development of information technology has particularly influenced the definition of the world as the global space, since moving to the farthest destinations today represents almost no problem. Relevant information about tourism trends indicates that the expansion of tourism started in the second half of the 20th century.

The first international tourism statistics from 1950 show about 25 million tourists who participated in the international tourism trends worldwide and the realized tourist consumption amounting to 2 million dollars. This means that tourism has grown from relative anonymity into one of the world's largest industries. According to WTTC, it contributes almost U.S. $\$ 6$ trillion to the global economy, with the participation of $9 \%$ of global GDP and it provides about 260 million jobs worldwide (100 million jobs directly in the tourism industry).

Regular monitoring of data on international tourist arrivals in certain years and regions of the world represents the basis for conducting a thorough analysis of the numerous changes that characterize the international tourist market, and that will enable us to reach conclusions regarding the flexibility and adaptability as well as the level of resistance of tourism to world events.

Looking at the data from Table 1, we can see the evident growth of international tourism trends with the exception of data in 2009. In 2000, the growth rate was $25.06 \%$ compared to the previous five-year period; the growth rate of $18.64 \%$ was recorded in 2005 compared to 2000, while in 2010, the growth rate amounted to $15.74 \%$ compared to 2005 . The suspended long growth rate of international movement in 2009 was certainly the result of the global economic crisis reflected in the tourism industry.

However, in 2010, there were over 22.5 million of international tourist arrivals compared to 2008 and 58.5 million or an increase of $6.67 \%$ compared to 2009 . These data certainly indicate very rapid recovery of the tourism as the consequence of financial crisis that can be viewed as a challenge in an effort to maintain the growth of international trends for the year, if we assume that the consequences of the financial crisis are still present in many countries.

As can be seen from the data in Table 1, the growth was recorded in 2010 compared to 2009 and it amounted to $3.20 \%$ for Europe, $12.53 \%$ for Asia and Pacific, $7.6 \%$ for America, $6.33 \%$ for Africa and $5.88 \%$ for the Middle East. Also, taken from the regions, we can conclude that the greatest growth of

Table 1: International tourist arrivals by region of the world (in millions)

\begin{tabular}{cccccccccc}
\hline Year & 1995 & 2000 & 2005 & 2006 & 2007 & 2008 & 2009 & 2010 \\
\hline WORLD & 540.9 & 681.3 & 808.3 & 841.9 & 908.3 & 913.0 & 877.0 & 935.5 \\
\hline Europe & 315.0 & 392.4 & 443.9 & 456.9 & 488.0 & 480.8 & 456.9 & 471.5 \\
\hline Asia \& Pacific & 82.8 & 109.3 & 156.2 & 167.4 & 185.4 & 184.1 & 181.1 & 203.8 \\
\hline America & 109.0 & 128.2 & 133.1 & 136.0 & 142.5 & 147.8 & 140.5 & 151.2 \\
\hline Africa & 20.4 & 27.0 & 36.7 & 40.9 & 44.9 & 44.4 & 45.8 & 48.7 \\
\hline Middle East & 13.7 & 24.4 & 38.4 & 40.7 & 47.5 & 55.9 & 52.7 & 60.3 \\
\hline
\end{tabular}


international tourism trends recorded in the Middle East is as follows: $78.10 \%$ in $2000,57.37 \%$ in 2005 and $57.03 \%$ in 2010 compared to the previous five-year period. These data confirm the predictions that the Middle East is recognized as the fastest growing tourism market, followed by Asia and the Pacific with an average growth rate of $35 \%$ for a period of twenty years, Africa with an average growth rate of $33.66 \%$, Europe with an average growth rate of $13.63 \%$, while the average growth rate of America is $11.67 \%$.

We can conclude that during the last decade the tourism expansion has been recorded at the international level, and according to all indicators, these trends will continue in the upcoming years. In fact, international tourism has become a significant area of economic development and the major factor in world economic trade.

All this indicates that tourism is a phenomenon whose impact could be felt in all spheres of economic and social life, which is why the issue of tourism development should be approached cautiously and deliberately.

\section{A brief overview of trends and predictions}

Travel industry today is the largest industrial branch with over 101 million people worldwide and gross sales of over U.S. \$2 trillion, accounting for $5.5 \%$ of world GDP. It should be noted that until 2008 in almost all regions of the world the pattern was one of a steady growth with the exception of a plateau between 2000 - 2003, as a result of events such as September 11, SARS and global economic stagnation.

In 2008, slightly below the predictions of the WTO, the number of tourists increased by $4 \%$, while the tourism industry accounted for $3.4 \%$ of the world GDP with the participation of $8.4 \%$ of those employed in tourism. In 2009, tourism industry accounted for 3.2\% of world GDP with the participation of $7.6 \%$ of employees.
Global tourism arrivals decreased by $4.2 \%$ in 2009 due to recession. Tourism receipts were 5.7\% below the 2008 level. The WTO forecasts generated U.S. $\$ 4.235 .5$ billion from tourism, which coincides with the prediction of the actual U.S. $\$ 4.3$ trillion according to the WTTC.

Also, it is necessary to point out the forecasts of the expected WTO U.S. $\$ 1.56$ billion by 2020 .

The forecasts put an emphasis on tourism as the major increasing factor in the world, with the real growth rate of $5 \%$ per year and possible 50 million of new jobs in the tourism industry.

The data on the total international arrivals shown in Table 2, speak in favor of the recorded growth to a ten-year period in all regions of the world. Regarding the average ten-year growth expressed as a percentage, we can conclude that the Middle East region particularly stands out in relation to other regions, followed by Asia and the Pacific, Africa, Europe and America.

If you carry out the analysis of the ten-year average growth of international tourist arrivals to the forecasts for 2020, we can conclude that the Middle East is also emphasized in relation to other regions, but with a significantly lower rate of $105.24 \%$, followed by Asia and the Pacific with $101.72 \%$, Africa with $70.66 \%$, Europe with $39.97 \%$, and the America with $47.97 \%$.

Ten-year average growth rate in relation to the envisaged international tourist arrivals at the world level would amount to $54.52 \%$.

We can conclude that predictions about tourism trends unfolding in the future are in favor of further development of tourism in the region and the growth of tourism indicators at the global level, putting special emphasis on Asia and the Pacific region and America. However, it is also necessary to emphasize prediction as a warning to factors such as climate change that can result in disaster, the terrorist attacks and diseases such as the "new" virus, which can negatively affect the flow of tourism.

Table 2: International tourism prospects: world and regional (in millions)

\begin{tabular}{cccccc}
\hline & \multicolumn{3}{c}{ Tourist arrivals } & \multicolumn{2}{c}{$\begin{array}{c}\text { Ten-year average } \\
\text { growth rate (\%) }\end{array}$} \\
\cline { 2 - 4 } & 1990 & 2000 & 2010 & & Forecast 2020 \\
\hline World total & 439.5 & 681.3 & 935.5 & 46.16 & 1602 \\
\hline Europe & 265.7 & 392.4 & 471.5 & 33.92 & 717 \\
\hline Asia \& Pacific & 56.2 & 109.3 & 203.8 & 90.47 & 457 \\
\hline America & 92.8 & 128.2 & 151.2 & 28.04 & 284 \\
\hline Africa & 15.2 & 27.0 & 48.7 & 79.00 & 75 \\
\hline Middle East & 9.6 & 24.4 & 60.3 & 150.64 & 69 \\
\hline
\end{tabular}


In addition, the predictions point out the possible occurrence of the "shock of poverty" with which the world mega centers can be confronted. This can further lead to the occurrence zones of instability and the interest of a larger number of tourists in the national parks and protected areas, such as Bolivia and Madagascar.

We can conclude that such forecasts are the result of numerous changes, new requirements, ways of thinking and the need for new global markets, that are caused by human behavior, but that will certainly affect their future behavior and consumption, which stems from the need to constantly evaluate all the factors to maintain harmony with the tourism market that is constantly subject to change.

\section{Modern information technology as a factor in tourism development}

Information technology is a complex system that includes computers and communications technology.

The emergence and development of computers have enabled fast, today almost simultaneous exchange of information as a final product of information technology, which represents knowledge, power and money in order to achieve adequate communication. It has always represented the basis through which people are able to exchange and share information, and thus understand and acquire new knowledge.

Modern information technology is a complex communication system that provides its customers a wide range of diverse services and products, in particular the Internet.

The Internet is a global computer network that connects computers around the world and enables direct communication between the users. The beginning of the so-called era of modern information technology as well as the creation and implementation of automated electronic reservation systems during the 60's of last century by major European companies (Lufthansa, British Airways, Air France) was marked by establishing strong links between modern information technology and tourism.

Since then, the tourism industry has become one of the largest users of modern information technology.

For tourism as a service activity, information is one of the most important factors. The Internet, as a product of information technology, also represents one of the most important instruments through which we can meet the increasingly diversified needs of tourists.

The need to attract visitors, satisfy their curiosity and persuade tourists to buy a product, that is, the need to produce the conditions for creation and implementation of tourism product as well as to provide conditions for re-return of the tourists who adequately meet their needs, is one of the basic tasks concerning the implementation of modern information systems in tourism.

\section{The interdependence of modern information technology and tourism}

Knowledge, last minute bookings, shorter but content - "rich" travel, the emphasis of quality service, good tourist product advertising on the tourist market - are the characteristics of today's "modern" tourists who have had great influence on the change of tourism strategies in the last ten years.

We can conclude that the contribution of modern information technology to the development of tourism and travel industry on a global scale has been enormous.

The interdependence of modern information technology and tourism can be viewed as:

- The aspects of modern information technology on tourism - which provides for the promotion, marketing and product differentiation through rapid, open and unrestricted access to any information anywhere in the world. This has led to the changed relationship with the traditional service providers and has caused the emergence of new destinations, thus increasing the competitiveness of the tourism market.

- The aspect of tourism on the development of modern information technology - tourism is today one of the most dominant economic sectors primarily owning to the growing tourism economy in the last 50 years.

"In order to build and maintain a comprehensive database of tourism products and the competitiveness of the tourism market, and create conditions for further facilitation of international tourism trends and avoid unnecessary administrative or fiscal constraints, it is necessary to support the financial investment in further 
development of information technologies and to encourage a series of measures related to education and training in information technology."

(Millennium Declaration, 2001)

When it comes to applying the modern information technology innovations, the best indicator of the implementation of new system software in the tourist industry is Global Distribution Systems (GDS), which is based on the application of modern information and communication technologies.

\section{Application of global distribution systems in tourism}

The first computerized reservation system (CRS) was created in the 60 s of the last century by the leading airline company. It is the predecessor of today's distribution system through which the work of agents is facilitated and their productivity increased. Namely, this system provides basic information concerning the schedule, prices and availability of seats.

Until the appearance of distribution systems, all tourist information and data on hotels, flights, renta-car companies were monthly printed in the form of thick brochures, which made the process of information exchange between airlines, travel agents and passengers much more difficult.

The return information process from the travel agency to passengers lasted more than 24 hours, which had a negative impact on service quality, passenger satisfaction and the revenue of travel agencies and airlines. Thus, one of the essential characteristics the timely information, was not achieved. In the mid 70's of the last century, due to the development of information technology, airlines allowed travel agencies to access their databases when the first reservation system emerged.

GDS represents a link which further connects the main factors of tourism with the intention to recognize the needs of tourists and to offer its customers modern information solutions that will create an integrated tourism product. This will further lead to the realization of the common goal - the pleasure of tourists and
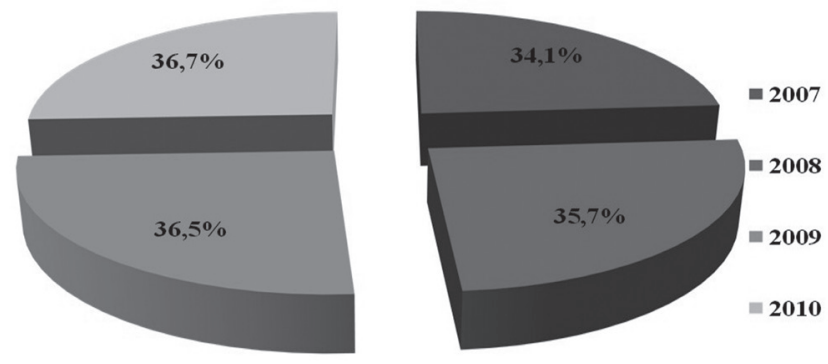

Figure 2: Global tourism market share of GDS Amadeus in the last four years

continued profits for all tourism operators. GDS and the Internet today represent electronic markets that connect travelers, travel agencies, airlines, hotels and car rental companies, with a share of U.S. $\$ 63$ billion in 2005 out of the total travel bookings compared to U.S. $\$ 23$ billion in 2001 .

There are many distribution systems on the world tourism market. According to the travel agency air bookings in 2009, GDS Worldspan had a share of $11 \%$, GDS Sabre participated with 25\%, GDS Galileo participated with $28 \%$ and GDS Amadeus participated with $33 \%$ of the global market share

The Figure 2 presents information on participation of GDS Amadeus on the global tourism market.

Based on the presented data, we can conclude that the continued growth of participation highlights the leading position of GDS Amadeus in the world tourism market. The global distribution systems are extremely important for the development of tourism, which can be best shown through the detailed presentation of the predominant GDS Amadeus. With the presentation of tasks, products and results of operations, we will attempt to give GDS Amadeus representation on the tourism market and its contribution to the tourism development in the world. 


\section{GDS AMADEUS}

GDS Amadeus was founded in 1987 by European airlines Air France (23.36\%), Lufthansa (18.28\%) and Iberia (18.28\%), which means that $59.92 \%$ of the company is owned by the three founder airlines, while the remaining $40.08 \%$ of shares are held publicly.

Network and database Amadeus system is among the largest civilian computer systems in the world and serves over 99.000 travel agencies in 195 countries, over 500 airlines and 34.000 airline sales offices, over 86.000 hotels, with 100 million overnight stays per year, 36.000 rent-a-car businesses (over 42 car rental companies), many tour operators and railway companies.

The headquaters of the Amadeus system are located in Madrid, Spain, while the center of the operational functioning of the company is situated in Erding, Germany and it is now one of the largest commercial computer centers in the world with the network AMANET and 15 computer centers which divert the data flow and control the traffic.

GDS Amadeus distributes identical software packages to all its providers in 217 markets with 76 local or regional offices. Functionality and modern solutions of GDS Amadeus have contributed greatly to it assuming the leading position with respect to the number of users, reservations and passengers.

The data from 2009, presented in Figure 3, highlight the leading position that GDS Amadeus assumes in almost all regions of the world, with the exception of North America (8.20\%).

Asia and the Pacific region recorded prevalence with $71.30 \%$, followed by Western Europe with $67.50 \%$, Africa with $61.30 \%$ and Latin America with $42.50 \%$.

We can conclude that the implementation of the GDS Amadeus leading information technology and creation of modern products are greatly responsible

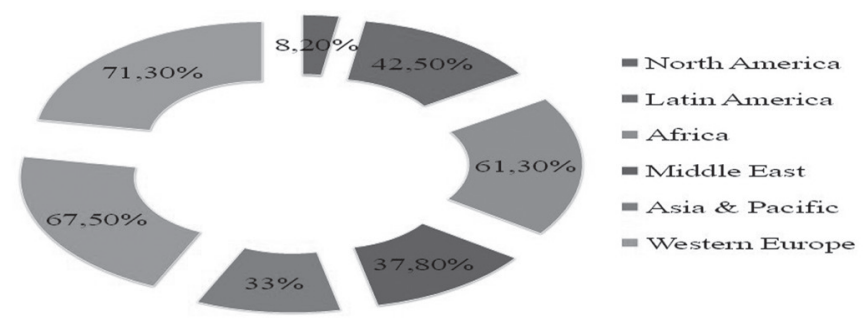

Figure3: GDS Amadeus - global market share leader for the existence of extensive networks of its users, as well as for developing a competitive advantage over other systems.

\section{Main activities and GDS Amadeus products}

The main tasks of GDS Amadeus present it as the leading information technology service provider for all industries that are directly or indirectly associated with tourism and travel.

The principal tasks of GDS Amadeus are as follows:

- Liaising with the travel agency through which they allow a quick and efficient reservation and services sales;

- Liaising with the airlines with the aim of effective occupancy of its capacity;

- Including Hotel Amadeus system to facilitate increased sales of hotels;

- The inclusion of rent-a-car company with the aim of expanding the network services;

- Providing information center related to innovation and training;

- Providing commercial and technical support to all customers.

GDS Amadeus products have multiple significance since they enable travel agencies to improve the range of services to their passengers, increase productivity through the use of fully automated processes, improve business efficiency and become more flexible in order to adapt to the specifics of the tourism market.

GDS Amadeus products, such as Pro Web, Vista, Check my trip, Central Ticketing Solution or Automatic MCO have been widely applied by Amadeus system users. Moreover, the choice of the particular product depends on the commitment and users' needs for everyday work with passengers.

The latest in a series of GDS products that encountered a wide acceptance by the users of the system is E-ticketing. It represents a new way of publishing documents, where the passenger does not receive a paper document, but is electronically registered as a buyer. Provision and payment take place as usual at the travel agency or on the Amadeus Web site. The passenger is obliged to report his identification number, which will be used during the check-up. Benefits of Eticketing are numerous: 


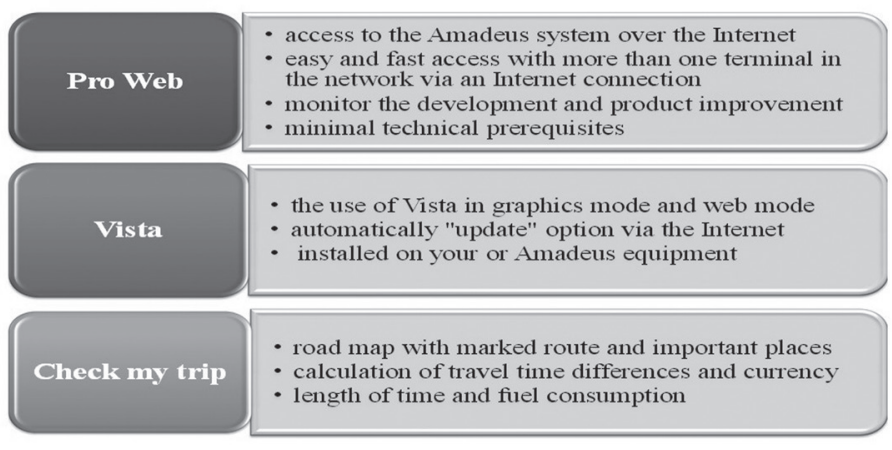

Figure 4: The range of products of GDS Amadeus

- compared to the passengers in a simple and practical procedure for the purchase;

- compared to the travel agency in reducing the time needed for paper tickets;

- compared to the airlines in reducing the costs of producing and distributing tickets.

\section{The basic structure of the GDS Amadeus Providers}

Over the last twenty years, GDS Amadeus has enjoyed significant year-on-year growth and produced wealth for providers and the communities it cooperates with. It is extremely important to point out that only in 2009, GDS Amadeus achieved approximately U.S. $\$ 87$ billion from the sale of tickets through all sales channels, out of which $71 \%$ came through travel agency channel which accounted for U.S. $\$ 62$ billion.

Regarding the Figure 5, GDS Amadeus business structure consists of the distribution of services and IT solutions that are available to many users "on line" 24 hours a day, seven days a week. Thus, the system users are able to present the updated information and services to the entire world market.
Starting from the fact that the development of tourism in the third millennium demands access to fast, open technology supported by specialist expertise, we can conclude that the GDS Amadeus has made an important contribution to the achievements of the global tourism and travel industries as a whole by using the intelligent application of technology and innovations. The benefits are numerous and are reflected in a significant number of system users, who by using these products, can make a considerable savings in operating costs, income generation, etc.

According to data from the Figure 6, we can see that the intensive growth, intense competition and pressure to make profit are the things that characterize today's tourist market, which means that only new technologies and innovative business models may be well placed to respond to the challenges.

For this purpose, a wide range of advanced technological solutions are offered by GDS Amadeus with the aim of allowing all its users to have equal share of the tourism industry market.

We would like to point out that IT solutions to individual providers are the result of the modular technology that is specifically tailored to meet the needs and characteristics of the products that are on offer to the users of the system, with a view of achieving effective business environment that will be characterized by efficient business processes and competitive position in the tourism market.

\section{GDS Amadeus business results}

The unique community approach to the development of IT solutions highlights the position of

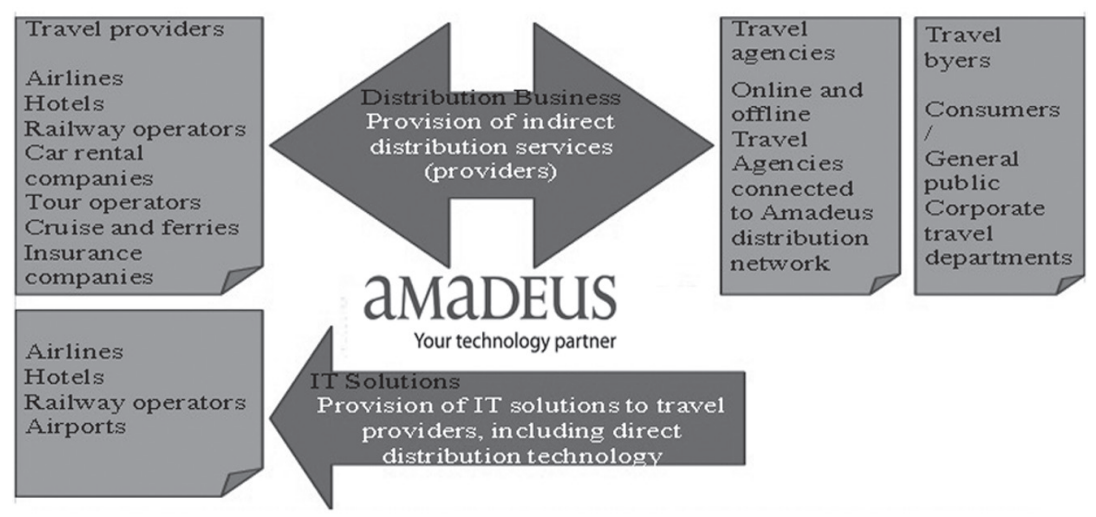

Figure 5: GDS Amadeus business structure 


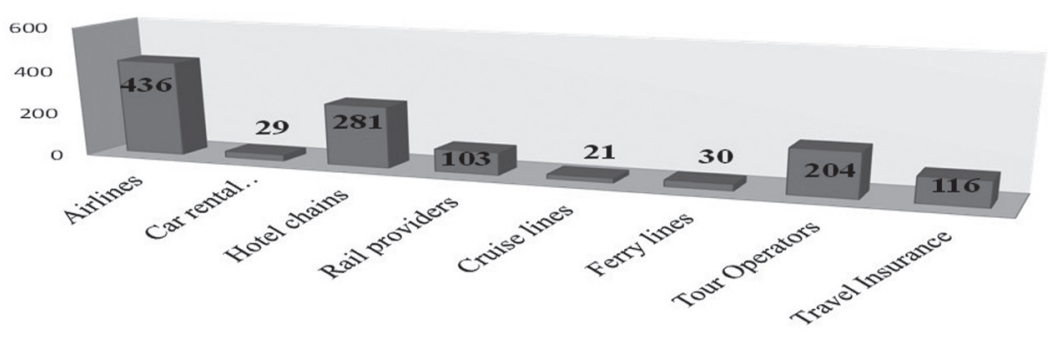

Figure 6: Available Amadeus providers in 2010

GDS Amadeus as a true partner to the customers. Benefits that users gain by applying the latest IT solutions are numerous and are mostly reflected in the global availability and higher value sales with the efficiency, target marketing and brand differentiation.

According to data presented in Figure 7, we can see that the largest number of GDS Amadeus offices is located in the region of Europe - a total of 55, followed by the region of America with 42 offices and Asia \& Pacific region with the total of 22 offices. We can conclude that the established broad network of GDS Amadeus is the result of the vision focused on both the commitment and results to ensure the future success of customers.

Cross-section of results achieved for the last four years can be best presented as the total number of reservations for all Amadeus providers, with the profit expressed in millions of $€$.

Table 3 contains data on the number of total reservations and adjusted profits for the last four years. Namely, there has been a decline of total reservations from $4.35 \%$ in 2009 . However, in the same year, a growth of $8.05 \%$ was recorded for adjusted profit over the previous year. In 2010, an increase of $2.66 \%$ of total reservations was recorded and the growth of $22.35 \%$ for adjusted profit compared to 2009.

These figures are the result of the GDS Amadeus commitment to new product and solution development, which recorded a growth of almost $60 \%$ for the last four years.
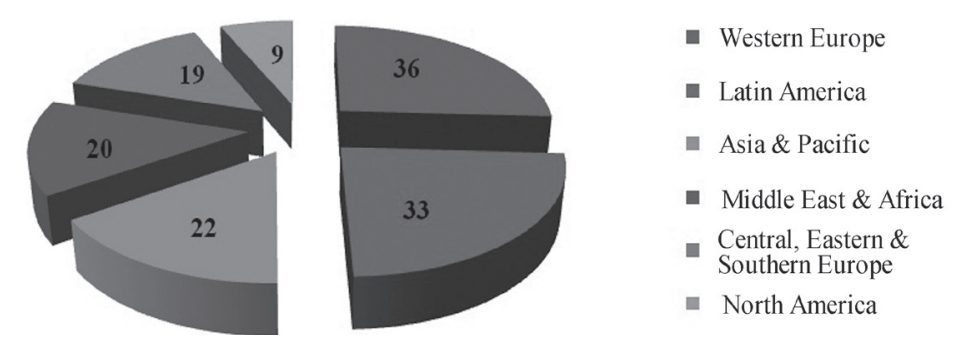

Figure 7: Number of Amadeus offices by region in 2010
Table 4 shows the full particulars of the registered growth of financial performance in 2010 compared to the previous year and to an increase of $8.50 \%$ for distribution services and an increase of $17.70 \%$ for Amadeus IT solutions. Based on the financial performance of GDS Amadeus, it should be noted that Amadeus allocates significant funds to research and development technologies used in the travel sector.

Only in 2009, GDS Amadeus set aside 250 million $€$, and in 2010, the European Commission ranked the investment of Amadeus as the largest in Europe by total research and development investment in both computer service category and the travel and tourism sectors.

Today, GDS Amadeus has one of the best fare search engines in the world powered by unique algorithms that can process more than 50 million transactions per day.

The fact that the GDS Amadeus was the first to receive the quality certification ISO9001:2000 stands in support of the continuous and systematic initiatives towards improving products and solutions.

\section{GDS AMADEUS STAFF}

Outstanding achievements are based on the contribution of every member of staff. Therefore, GDS Amadeus aims to improve the position of every employee through incentives that would make it a great place to work, a place where success is recognized, where innovation is encouraged and where employees are empowered to achieve their professional goals.

Looking at the data presented in Table 5 and 6, we can conclude that the GDS Amadeus allocates great attention to providing continuous training to its employees in order to achieve efficient operations as well as personal development goals, with the aim to further their careers in the organization. It should be noted that $77 \%$ of employees in GDS Amadeus hold a university degree or higher, while $85 \%$ of the employees speak two or more languages. Also, every year, a large number of young graduates are to be engaged in the GDS Amadeus, where 
Table 3: The intersection of the total bookings and adjusted profit by age (in millions)

\begin{tabular}{ccc}
\hline & Total bookings & Adjusted profit \\
\hline 2007 & 428 & 281 \\
\hline 2008 & 431 & 323 \\
\hline 2009 & 413 & 349 \\
\hline 2010 & 442 & 427 \\
\hline
\end{tabular}

Table 4: Cross section of the financial performance of GDS Amadeus (in million EUR)

\begin{tabular}{ccc}
\hline & Distribution financial performances & IT financial performances \\
\hline 2009 & 1,836 & 511 \\
\hline 2010 & 1,992 & 601 \\
\hline
\end{tabular}

Table 5: Total Amadeus workforce

\begin{tabular}{cccc}
\hline & 2008 & 2009 & 2010 \\
\hline Permanent staff & 7,422 & 7,521 & 7,852 \\
\hline Temporary staff & 119 & 108 & 108 \\
\hline External manpower & 1,338 & 1,759 & 2,31 \\
\hline Total staff & 8,880 & 9,388 & 10,270 \\
\hline
\end{tabular}

they are given a chance to achieve long-term career. GDS Amadeus also offers over 450 e-learning courses; annual performance and development interviews are the part of the ongoing performance management process.

\section{CONCLUSION}

Today's dynamic environment, which can be characterized as unstable and unpredictable, significantly affects the development of the tourism industry by setting the problem of "placement" of tourism products to the tourism market due to increased competitive pressure caused by the globalization of the services sector.

The trend of globalization is a result of the omnipresence of the worldwide product development and information technology. Moreover, it increases the complexity of the tourism industry and enforces understanding of the management of tourism development as a process that is based on constant research and ongoing analysis of the positions on the tourism market. The tourism sector is undergoing constant development and progression, and thus requires a comprehensive approach to all its com-
Table 6: Total hours of training

\begin{tabular}{ccc}
\hline 2008 & 2009 & 2010 \\
\hline 134,868 & 142,574 & 151,812 \\
\hline
\end{tabular}

ponents. After conducting research, we have come to the following conclusions:

- Numerous changes in the demographic, economic, psychographic, and other characteristics of tourists have been recorded in recent years, thus leading to major changes in the tourist demand.

Quick and frequent changes that characterize the tourism market require the appropriate action. In our opinion, the only feasible strategy should involve the following: adequate preparation, identifying changes in the environment, flexibility in relation to the emerging changes and accepting changes as the challenge in order to provide a competitive advantage.

- Changes in technologies enable the development of information technology and the Internet as a distribution channel, through which the connection between tourism supply and demand is electronically created. The products of modern information technology provide for the efficient reception, efficient data processing and rapid data transmission, which further results in improving business 
processes in numerous areas, especially in the field of transport and travel industry

- As products of modern information technology, Global Distribution Systems are particularly important for tourism development because they allow users to access information anywhere in the world and offer them the opportunity to create better and more complete service through the timely launching of products on the tourist market.

- GDS Amadeus assumes the leading position in relation to other distribution systems, primarily due to the development of software that is tailored specifically to meet the needs of individual users, allowing the availability and exchange of quality information to a large number of users, thus linking tourism related companies in the global networks.

Amadeus GDS has a wide range of products, distribution and IT solutions. Their quality and rapid transmission have enabled the presentation of tourist services in the tourist market, and thus have made the tourism products available to various groups of customers in a simple and efficient way. The total research and development investment of GDS Amadeus in both computer services category and the travel and tourism sector is very important, which is why its contribution is reflected in the field of tourism industry.

Finally, we would like to emphasize that the development and implementation of modern information technology products, in our opinion, represent a response to constant and rapid changes that characterize the tourist market and the chance to gain competitiveness and foster further development of tourism at the global level.

\section{REFERENCES}

Amadeus Annual Report 2010 [online]. Available from: http://www.cinven.com/lib/docs/092640-amadeusannualreport2010.pdf [accessed 22 May 2011].

Amadeus Customer IT Solutions [online]. Available from: http://www.amadeus.com/amadeus/x5140.html [accessed 22 May 2011].

Babu, S., Mishra, S., Parida, B. (2008) Tourism Development Revisited: concepts, issues and paradigms. London: Sage Publications.

Boniface, B., Cooper, C. (2005) Worldwide destination: the geography of travel and tourism. 4th ed. Oxford: Elsevier.
Buhalis, D., Costa, C. (2006) Tourism Business Frontiers: consumers, products and industry. Oxford: Elsevier, Butterworth Heinemann.

Buhalis, D., Costa, C. (2006) Tourism Management Dynamics: trends, management and tools. Oxford: Elsevier, Butterworth Heinemann.

Evans, N., Campbell, D., Stonehouse, G. (2002) Strategic Management for Travel and Tourism. Oxford: Butterworth Heinemann.

Goeldner, C., Brent, R. (2009) Tourism: Principles, Practices and Philosophies. 11th ed. Hoboken, N.J.: John Wiley.

Krstić, B., Stepanović, Lj. (2004) Avio saobraćaj u turbulencijama. Beograd: Goregraf. (in Serbian).

Lickorish, L., Jenkins, C. (2001) An introduction to Tourism. Oxford: Butterworth-Heinemann.

Millennium Declaration. 14th session of the General Assembly of the WTO, 2001 Osaka. Available from: http:// www.traveldailynews.com/pages/show_page/1318WTO's-Osaka-Millennium-Declaration [accessed 20 May 2011].

Page, S. (2009) Tourism Management: Managing for Change. 3rd ed. Oxford: Elsevier.

Pender, L., Sharpley, R. (2005) The Management of Tourism. London: Sage Publications.

Samipatra Das HVS International (2001) Global Distribution Systems in Present Times [online]. Available from: http://www.hospitalitynet.org/news/4013406.html [accessed 22 May 2011].

Tourism and World Economy. UNWTO [online]. Available from: http://www.unwto.org/facts/eng/economy. htm [accessed 01 June 2011].

Tourism Economic Research. World Travel and Tourism Council [online]. Available from: http://www.wttc.org/ eng/Tourism_Research/Tourism_Economic_Research [accessed 24 May 2011].

Tourism Facts and Figures. UNWTO [online]. Available from: http://media.unwto.org/en [accessed 24 May 2011].

Tourism Market Trends. UNWTO [online]. Available from: http://www.unwto.org/facts/eng/tmt.htm [accessed 01 June 2011].

Tribe, J. (2004) The Economics of Recreation, Leisure \& Tourism. 3rd ed. Oxford: Elsevier Ltd.

Unković, S., Čačić, K., Bakić, O. (2002) Savremena kretanja na turističkom tržištu. Beograd: Ekonomski fakultet. (in Serbian).

World Tourism Barometer. UNWTO [online]. Available from: http://mkt.unwto.org/en/barometer/september2011-interim-update [accessed 04 June 2011]. 


\section{ULOGA I POTENCIJAL GLOBALNOG DISTRIBUCIONOG SISTEMA AMADEUS ZA RAZVOJ TURIZMA NA GLOBALNOM NIVOU}

\section{Rezime:}

Globalizacija, razvoj i primena novih tehnologija, novi potrošački trendovi, briga za prirodno okruženje i mnogi drugi faktori, doprineli su raznolikosti i složenosti turističke industrije. Iz navedenih razloga, turistička industrija u proteklih nekoliko godina nastoji da usmeri svoje aktivnosti ka razvoju informacione i tehnološke infrastrukture, odnosno globalne elektronske povezanosti sa ciljem prevazilaženja graničnih barijera i uspostavljanja odnosa kako sa pružaocima usluga i turistima, tako i sa turističkim agencijama i organizatorima putovanja. Razvoj informacionih tehnologija i evolucija rezervacionih sistema pojedinih avio kompanija doveli su do nastanka Globalnih Distribucionih Sistema (GDS), poznatijih širom sveta kao kompjuterski rezervacioni sistemi koji elektronskim putem povezuju turističku ponudu sa turističkom potražnjom.

Cilj ovog ovog rada je da se prikaže uloga i značaj vodećeg distribucionog sistema (GDS Amadeus), kako bi se istakla njegova uloga u razvoju turizma na globalnom nivou. Istraživanje i metodologija ovog rada zasnovani su na analizi podataka dobijenih iz primarnih i sekundarnih izvora, putem kojih ćemo koristeći deduktivni pristup teorijskih postavki i analitički pristup kvantitativnih pokazatelja doći do značajnih saznanja. Na kraju ovog rada kroz zaključno razmatranje, nastojaćemo da pokažemo naučnu opravdanost sprovedenog istraživanja, tako što ćemo ukazati na značaj kontinuiranog nadzora i prilagođavanja promenama na turističkom tržištu, kako bismo ukazali na važnost primene informacionih tehnologija za razvoj turizma.

Ključne reči:

globalizacija, turizam, informacione tehnologije, GDS Amadeus.

Received: October 6th, 2012 Correction: December 18th, 2012

Accepted: January 10th, 2013 